\title{
Congestive Heart Failure
}

National Cancer Institute

\section{Source}

National Cancer Institute. Congestive Heart Failure. NCI Thesaurus. Code C3080.

Failure of the heart to pump a sufficient amount of blood to meet the needs of the body tissues, resulting in tissue congestion and edema. Signs and symptoms include shortness of breath, pitting edema, enlarged tender liver, engorged neck veins, and pulmonary rales. 